\title{
Kadar Pelepasan Bromokarbon Jangka Hayat Pendek oleh Rumpai Laut Tropika menggunakan Simulasi Laut Tropika
}

(Release Rates of Very Short-Lived Bromocarbon by Tropical Seaweeds using Tropical Sea Simulation)

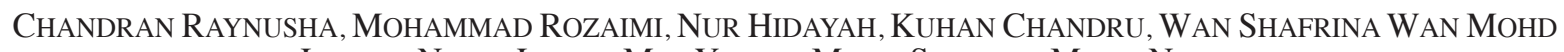
JAAFAR, NOOR LIANA MAT YAJIT \& MOHD SHAHRUL MOHD NADZIR*

\section{ABSTRAK}

Bagi negara tropika yang mempunyai keberhasilan marin yang tinggi seperti Malaysia, makroalga (rumpai laut) telah menjadi penyumbang utama kepada pelepasan bromokarbon jangka hayat pendek (VSL) ke dalam atmosfera. Faktor abiotik seperti keamatan cahaya dan kepekatan klorofil a telah diketahui mempengaruhi pengeluaran bromokarbon oleh rumpai laut, namun begitu masih lagi kurang kajian yang mengukur secara sistematik pengaruh rumpai laut terhadap kadar pelepasan bromokarbon VSL dijalankan. Oleh itu, sistem pengkulturan rumpai laut yang diselaraskan dengan keadaan persekitaran semula jadi disediakan bagi mengkaji kadar pelepasan bromokarbon $\mathrm{VSL}_{(}\left(\mathrm{CH}_{2} \mathrm{Br}_{2}, \mathrm{CHBr}_{3}\right.$ dan $\mathrm{CHBr}_{2} \mathrm{Cl}$ ) bagi tujuh rumpai laut merah, perang dan hijau iaitu Gracilaria changii, Ulva reticulata, Caulerpa racemosa var. macrophysa, Kappaphycus alvarezii, Sargassum binderi, Sargassum siliquosum dan Padina australis. Penghasilan bromokarbon VSL menunjukkan kitaran diurnal dengan kepekatan halokarbon meningkat kepada tahap maksimum pada waktu tengahari (1738 pmolL - $^{-1}$ ) dan menurun apabila keamatan cahaya dan suhu permukaan laut (SST) berkurang. Penghasilan bromokarbon VSL rumpai laut yang diletakkan di bawah cahaya matahari adalah lima kali ganda lebih tinggi daripada penghasilan tangki akuakultur yang diletakkan dalam persekitaran gelap yang menunjukkan berlakunya penghasilan fotokimia. Purata kadar penghasilan fotokimia untuk bromokarbon VSLdaripada uji kaji tangki akuakultur berjulat antara 1 dan 137 pmol per $g^{-1} F W^{-1} h^{-1}$. Ini menjadikan rumpai laut merah (Gracilaria changii) sebagai pengeluar tertinggi. Begitu juga, bromoperoksida (BPO) yang diekstrak daripada kesemua rumpai laut juga menunjukkan aktiviti tertinggi dalam rumpai laut merah diikuti oleh rumpai laut perang dan hijau.

Kata kunci: Bahan jangka hayat pendek (VSLS); bromokarbon jangka hayat pendek (VSL); rumpai laut

\section{ABSTRACT}

Macroalgae (seaweeds) are a major contributor in emitting very short-lived (VSL) bromocarbons into the atmosphere especially in tropical countries with high primary productivity such as Malaysia. Abiotic factors such as light intensities and chlorophyll a concentrations can influence the production of bromocarbons emitted by seaweeds, however, not many studies have systematically quantified their influence on the release rates of VSL bromocarbons. Hence, to measure this, we used a seaweed culture system mimicking a natural environment to study the release rate of VSL bromocarbons $\left(\mathrm{CH}_{2} \mathrm{Br}_{2}\right.$, $\mathrm{CHBr}_{3}$ and $\mathrm{CHBr}_{2} \mathrm{Cl}$ ) for several red, brown and green seaweeds (Gracilaria changii, Ulva reticulata, Caulerpa racemosa var. macrophysa, Kappaphycus alvarezii, Sargassum binderi, Sargassum siliquosum, and Padina australis. The production of VSL bromocarbons showed a diurnal cycle with halocarbon concentrations increasing to a maximum level at mid-day (1738 pmolL $\left.^{-1}\right)$ and decreasing when light intensity and SST decreased. The production of VSL bromocarbons of seaweeds kept in the sunlight is five times higher than the production of aquaculture tanks placed in dark environments indicating the occurrence of photochemical production. The average photochemical rate for VSL bromocarbons from aquaculture tank experiments ranges from 1 to $137 \mathrm{pmol}$ per $\mathrm{g}^{-1} \mathrm{FW}^{-1} \mathrm{~h}^{-1}$. This makes the red seaweeds (Gracilaria changii) as the highest. Likewise, bromoperoxide (BPO) extracted from all seaweeds also showed the highest activity in red seaweed followed by brown and green seaweed.

Keywords: Seaweeds; very short-lived (VSL) bromocarbon; very short-lived substances (VSLS)

\section{PENDAHULUAN}

Kajian terkini ini telah menunjukkan betapa pentingnya bahan berhalogen jangka hayat pendek (VSLS) dan potensi peranan bahan ini terhadap penipisan lapisan ozon (Aschmann et al. 2009; Keng et al. 2013). Majoriti halokarbon yang dikeluarkan oleh alga laut mempunyai jangka hayat pendek di atmosfera (Leedham et al. 2013).
Istilah bahan jangka hayat pendek (VSLS) merujuk kepada sebatian yang mengandungi halogen dengan jangka hayat kurang daripada enam bulan (Nadzir et al. 2014; Robinson et al. 2014). Laut merupakan sumber untuk bromokarbon jangka hayat pendek seperti dibromometana $\left(\mathrm{CH}_{2} \mathrm{Br}_{2}\right)$, bromodiklorometana $\left(\mathrm{CHBrCl}_{2}\right)$ dan bromoform $\left(\mathrm{CHBr}_{3}\right)$ melalui organisma marin seperti makroalga dan 
fitoplankton yang membantu di dalam proses pertukaran dari permukaan laut ke atmosfera (Raimund et al. 2011). Di dalam kajian Mithoo-Singh et al. (2017), majoriti sumber pelepasan halokarbon dihasilkan oleh makroalga yang menyumbang kepada kira-kira $70 \%$ daripada bromoform dunia, dan ia memberi kesan kepada fenomena perubahan iklim.

Organisma marin terutamanya rumpai laut menghasilkan sejumlah besar bahan kimia berunsur biogen (Lim et al. 2017; Yip et al. 2014). Rumpai laut menghasilkan juga sebatian halomatabolik yang terkandung di dalam vesikle yang dilitupi oleh membran alga dan ia ditafsirkan berkait rapat dengan aktiviti pemangkin haloperoksida (Almeida et al. 2001; Kongkiattikajorn \& Pongdam 2006). Haloperoksida merupakan salah satu enzim berciri terbaik di dalam alga laut yang memangkinkan penghalogenan sebatian organik (bromida, iodida dan klorida) dengan kehadiran hidrogen peroksida $\left(\mathrm{H}_{2} \mathrm{O}_{2}\right)$ (Shimonishi et al. 1998). Enzim ini memerlukan kedua-dua $\mathrm{H}_{2} \mathrm{O}_{2}$ (atau peroksida organik) dan satu ion halida untuk mengubah substrat yang ketiga (organik atau bukan organik) secara peroksida yang ditemani oleh hasil akhir yang terikat dengan ikatan kovalen antara atom halogen (Jittam et al. 2009). Tindak balas yang diaruhkan secara biologi mengumpulkan halida daripada air laut dan melepaskan pelbagai jenis halogen organik seperti $\mathrm{CH}_{3} \mathrm{I}, \mathrm{CH}_{3} \mathrm{Br}, \mathrm{CH}_{3} \mathrm{Cl}$ dan $\mathrm{CH}_{2} \mathrm{Br}_{2}$ ke atmosfera (Collén et al. 1994; Itoh et al. 1997; Itoh \& Shinya 1994; Wever 1988; Wever et al. 1991). Kajian inkubasi telah menunjukkan peningkatan pengeluaran bromokarbon dengan penambahan $\mathrm{H}_{2} \mathrm{O}_{2}$ kepada sampel alga dan penurunan dalam pengeluaran bromokarbon dengan penambahan perencat peroksida (Leedham et al. 2013) seterusnya mencadangkan peranan haloperoksida di dalam pengeluaran halokarbon oleh alga marin.

Kadar pengeluaran halokarbon kebiasaannya lebih tinggi untuk alga tropika berbanding spesies alga di temperat (Phang et al. 2015). Di negara tropika seperti Malaysia, pelepasan gas jangka hayat pendek (VSL) diangkut cepat oleh perolakan lapisan tropika dalam kepada lapisan bawah stratosfera tropika dan memberi kesan signifikan pada ozon stratosferik dunia (Carpenter et al. 2014). Pada masa kini, terdapat banyak kajian mengenai halokarbon jangka hayat pendek yang dihasilkan secara biologi oleh rumpai laut di habitat semula jadi dan rumpai laut di kawasan pengkulturan telah dijalankan di Malaysia (Leedham et al. 2015, 2013; Mithoo-Singh et al. 2017; Phang et al. 2015). Meskipun bromokarbon telah dikaji secara meluas dalam bidang marin, dalam kajian ini kami mensasarkan untuk mengkaji faktor seperti keamatan cahaya dan kepekatan klorofil $a$ (chl-a) yang mempengaruhi pengeluaran bromokarbon $\mathrm{CHBr}_{3}, \mathrm{CH}_{2} \mathrm{Br}_{2}$, dan $\mathrm{CHBrCl}_{2}$ oleh rumpai laut di kawasan perairan yang terpilih di Malaysia. Kawasan kajian yang dipilih ialah di Cape Rachado di Port Dickson (PD) dan Tanjung Balau (TB) di Johor. Selain daripada itu, penyelidikan ini juga bertujuan untuk mengkaji aktiviti BPO di dalam rumpai laut yang terpilih dan hubungannya terhadap penghasilan bromin jangka hayat pendek (VSL).

\section{BAHAN DAN KAEDAH}

Sistem 'hembusan dan tangkap' atau purge and trap (P\&T) (Teledyne Tekmar, USA) yang digunakan adalah sama dengan keadaan optimum yang dibangunkan oleh Auer et al. (2006). Sampel air laut telah dimasukan ke dalam bikar tertutup sistem P\&T yang juga disambungkan terus kepada Kromatografi Gas (Agilent Technology 7693A, USA) yang dilengkapi dengan pengesan penangkapan elektron (ECD) $63 \mathrm{Ni}$ yang beroperasi pada suhu $275^{\circ} \mathrm{C}$. Terma GC-ECD akan digunakan dalam perenggan berikutnya. Kesemua sampel air (isi padu $10 \mathrm{~mL}$ ) telah ditapis melalui penapis gentian kaca dengan saiz pori $0.2 \mu \mathrm{m}$ (GFC, Whatman) untuk menyingkirkan mikroorganisma sebelum suntikan dilakukan. Setiap $10 \mathrm{~mL}$ sampel air laut dihembus oleh gas nitrogen (purged) dengan kadar aliran nitrogen 40 $\mathrm{mL} \min ^{-1}$ selama 12 min pada suhu $80^{\circ} \mathrm{C}$ dan kemudian ia disampel melalui perangkap (trap) VOCARB 3000 dengan sebatian yang disasarkan diserap pada suhu $25^{\circ} \mathrm{C}$ dan dipanaskan sehingga suhu $270^{\circ} \mathrm{C}$ selama 4 min dengan

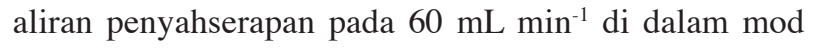
penyahserapan.

Keadaan kromatografi sama seperti dalam kajian Ekdahl et al. (1998), ia bermula dengan suhu $40^{\circ} \mathrm{C}$ dan kemudiannya dinaikkan kepada $60^{\circ} \mathrm{C}$ pada kadar $5^{\circ} \mathrm{C}$ $\min ^{-1}$. Selepas itu, suhu ditingkatkan kepada $120^{\circ} \mathrm{C}$ pada kadar $20^{\circ} \mathrm{C} \min ^{-1}$. Suhu kemudiannya dikekalkan kepada $120^{\circ} \mathrm{C}$ selama $16 \mathrm{~min}$. Jenis kolum yang digunakan oleh GC adalah DB-1701, $30 \mathrm{~m} \times 0.32 \mathrm{~mm}$ i.d ketebalan filem $0.15 \mu \mathrm{m}$ (J\&W Scientific, USA). Gas nitrogen tulen telah digunakan untuk kedua-dua gas pembawa dan gas aliran pada kadar aliran $15 \mathrm{~mL} \mathrm{~min}{ }^{-1}$. Puncak pengenalpastian dan pengkuantitian telah dilakukan oleh penentukuran dalaman dan penentukuran berbilang titik dengan larutan piawai yang disediakan.

\section{KEADAAN PENGKULTURAN}

Sampel rumpai laut yang telah dikumpul (Jadual 1) diletakkan di dalam tangki $(2 \mathrm{~m} \times 1 \mathrm{~m} \times 0.3 \mathrm{~m})$ dengan pengaliran air laut untuk mengekalkan kesegarannya di dalam tangki pengkulturan rumah hijau. Rumpai laut dibilas perlahan dengan menggunakan air laut yang ditapis sebelum setiap uji kaji dijalankan. Rumpai laut yang berada di dalam tangki diletakkan pada keadaan suhu dan cahaya semula jadi untuk membolehkan kitaran diurnal pelepasan VSL daripada rumpai laut berlaku seperti dalam persekitaran semula jadi. Teknik uji kaji ini sama seperti yang digunakan oleh Laturnus (1996) kecuali pemindahan air laut daripada tangki dibuat dengan menggunakan botol $1000 \mathrm{~mL}$ dengan pengaduk magnet diletakkan di bawah setiap botol untuk memberikan pencampuran medium yang mencukupi sepanjang tempoh uji kaji dijalankan. Botol ditutup dengan menggunakan foil aluminium bagi mengelakkan tindak balas halokarbon terjadi disebabkan 
JADUAL 1. Senarai spesies rumpai laut yang diperoleh untuk uji kaji kadar penghasilan bromokarbon VSLS

\begin{tabular}{|c|c|c|c|}
\hline Nama spesies & Pengelasan & Ciri-ciri morfologi strain & Tempat strain diambil \\
\hline Ulva reticulata & Chlorophyta & Hijau dan panjang & $\begin{array}{l}\text { Cape Rachado, Port Dickson } \\
\text { Morib, Banting }\end{array}$ \\
\hline Caulerpa racemosa var. macrophysa & Chlorophyta & Anggur hijau bercabang & $\begin{array}{l}\text { Cape Rachado, Port Dickson } \\
\text { Tanjung balau, Johor }\end{array}$ \\
\hline Gracilaria changii & Rhodophyta & Bercabang & Kuala Selangor \\
\hline Kappaphycus alvarezii & Phaeophyta & Perang dan bercabang pendek & $\begin{array}{l}\text { Pusat pengkulturan rumpai laut, } \\
\text { Pangkor Island }\end{array}$ \\
\hline Sargassum binderi & Phaeophyta & $\begin{array}{l}\text { Tumbuh di pasang surut berbatu } \\
\text { atau terumbu karang, terampai. }\end{array}$ & $\begin{array}{l}\text { Cape Rachado, Port Dickson } \\
\text { Tanjung Balau, Johor }\end{array}$ \\
\hline Sargassum siliquosum & Phaeophyta & $\begin{array}{l}\text { Tumbuh di pasang surut berbatu or } \\
\text { terumbu karang, terampai. }\end{array}$ & $\begin{array}{l}\text { Cape Rachado, Port Dickson } \\
\text { Tanjung Balau, Johor }\end{array}$ \\
\hline Padina australis & Phaeophyta & & $\begin{array}{l}\text { Cape Rachado, Port Dickson } \\
\text { Tanjung Balau, Johor }\end{array}$ \\
\hline
\end{tabular}

cahaya. Medium air laut juga ditukar setiap minggu untuk mengelakkan limitasi nutrien dan meminimumkan pencemaran daripada mikroorganisma lain terjadi.

\section{PARAMETER DAN ANALISIS SAMPEL}

Rumpai laut yang berbeza jenis (merah, hijau dan perang) dipisahkan dan diletakkan di dalam tiga botol $1000 \mathrm{~mL}$ yang mengandungi air laut. Parameter biologi seperti keamatan cahaya, suhu dan kandungan chl- $a$ direkodkan selama 12 jam pada keadaan waktu siang hari dan keadaan waktu malam hari sebelum dianalisis menggunakan P\&T dan GC-ECD. Chl- $a$ diukur menggunakan fluorometer (AquaFluor, USA) manakala keamatan cahaya ditentukan mengunakan meter cahaya (EasyView, USA). Selepas itu, $10 \mathrm{~mL}$ air laut diekstrak dengan menggunakan $10 \mathrm{~mL}$ picagari kedap gas dan dipindahkan ke dalam $10 \mathrm{~mL}$ vial gelap dan dianalisis dengan segera menggunakan GC-ECD. $10 \mathrm{~mL}$ sampel air laut diukur sebanyak empat kali untuk setiap analisis yang dilakukan. Pengukuran dibuat berdasarkan pengelasan spesies. Pengukuran kadar pengeluaran 12 jam VSLS bromokarbon dilakukan terhadap semua spesies dan mengambil masa selama dua bulan.

\section{PENGEKSTRAKAN ENZIM BPO DARI RUMPAI LAUT}

Sebelum pengekstrakan dilakukan, rumpai laut dibersihkan dengan cara digosok dan dibilas menggunakan air laut. Pengekstrakan enzim mentah dilakukan di dalam penghomogenat (homogenizer) dengan $100 \mathrm{~g}$ rumpai laut terampai di dalam $100 \mathrm{~mL}$ larutan penimbal $50 \mathrm{mM}$ Tris-SO4 (pH7.4) selama 1-2 min. Homogenat yang terhasil dikumpulkan dan ditapis melalui penapis jenis miracloth. Sisa kemudiannya terampai semula di dalam $500 \mathrm{~mL}$ larutan penimbal yang sama, dihomogenat dan ditelah ditapis kembali. Ekstrak sel bebas diperoleh oleh emparan pada $12,000 \times$ g selama 30 min di bawah suhu $5^{\circ} \mathrm{C}$ menggunakan pengempar (Eppendorf $5804 \mathrm{R}$, Thomas Scientific, USA).

\section{CERAKINAN ENZIMATIK}

Aktiviti enzim ditentukan pada suhu bilik dengan menggunakan monochlorodimedone (MCD, Alfa Aesar) sebagai substrat di dalam campuran tindak balas yang mengandungi $20 \mathrm{mM} \mathrm{KBr}, 60 \mu \mathrm{M} \mathrm{MCD}, 2 \mathrm{mM} \mathrm{H}_{2} \mathrm{O}_{2}$, larutan penimbal 100 mM Tris-SO4 (pH7.4) dan ekstrak enzim di dalam jumlah akhir sebanyak $1 \mathrm{~mL}$. Penurunan dalam penyerapan MCD pada $290 \mathrm{~nm}\left(\varepsilon=1.99 \times 104 \mathrm{M}^{-1} \mathrm{~cm}^{-1}\right)$ ialah apabila bromin dipantau dari semasa ke semasa di dalam spektrofotometer Thermo Spectronic Genesis UVVis. Satu unit bromoperoksida (BPO) ditakrifkan sebagai jumlah enzim yang diperlukan untuk membentuk $1 \mu \mathrm{mol}$ bromochlorodimedone dalam satu minit. Penentuan protein dilakukan mengikut kaedah Lowry et al. (1954). Kandungan protein di dalam ekstrak enzim ditentukan berdasarkan kaedah Lowry yang menggunakan Bovine Serum Albumin (BSA) sebagai piawai.

\section{HASIL DAN PERBINCANGAN}

PELEPASAN BROMOKARBON DARIPADA RUMPAI LAUT

Berdasarkan Jadual 2, kepekatan yang tertinggi $\mathrm{CH}_{2} \mathrm{Br}_{2}$ dilepaskan oleh Gracilaria changii dan diikuti oleh $\mathrm{CHBr}_{3}$ dan $\mathrm{CHBr}_{2} \mathrm{Cl}$ pada waktu tengahari dengan nilai 1738 pmolL $^{-1}, 712$ pmolL $^{-1}$ dan 319 pmolL $^{-1}$ untuk $\mathrm{CH}_{2} \mathrm{Br}_{2}, \mathrm{CHBr}_{3}$ dan $\mathrm{CHBr}_{2} \mathrm{Cl}$. Hasil kajian ini juga dikaji di dalam kajian terdahulu dengan pelepasan sebatian bromin tinggi datangnya daripada makroalga perang dan merah berbanding makroalga hijau (Carpenter et al. 2000; Ekdahlet al. 1998; Leedham et al. 2013; Mithoo-Singh et al. 2017; Nightingale et al. 1995).

Rumpai laut perang seperti Kappaphycus alvarezii melepaskan $\mathrm{CHBr}_{3}$ yang lebih tinggi berbanding Gracilaria changii dengan nilai maksimum 1077 pmolL $^{-1}$ diikuti Sargassum binderi (392 pmolL-1), Sargassum siliquosum (125 pmolL ${ }^{-1}$ ) dan Padina australis (39 pmolL $^{-1}$ ) (Rajah 1). Pengeluar tertinggi untuk rumpai laut hijau ialah Ulva reticulata, yang melepaskan $93.5 \mathrm{pmolL}^{-1}$ 
JADUAL 2. Kepekatan halokarbon minimum dan maksimum di dalam tangki yang mengandungi air laut untuk pelbagai jenis rumpai laut selama tempoh 24 jam

\begin{tabular}{lcccccc}
\hline \multirow{2}{*}{ Sampel } & \multicolumn{2}{c}{$\mathrm{CH}_{2} \mathrm{Br}_{2}$} & \multicolumn{2}{c}{$\mathrm{CHBr}_{2} \mathrm{Cl}$} & \multicolumn{2}{c}{$\mathrm{CHBr}_{3}$} \\
\cline { 2 - 7 } & $\min$ & $\max$ & $\min$ & $\max$ & $\min$ & $\max$ \\
\hline Air laut kawalan & 0.80 & 2.50 & 0.80 & 4.00 & 4.30 & 21.20 \\
Ulva reticulata & 7.33 & 29.43 & 2.30 & 18.27 & 6.63 & 92.49 \\
Caulerpa racemosa var. macrophysa & 1.13 & 6.95 & 1.17 & 8.17 & 3.63 & 29.33 \\
Gracilaria changii & 82.33 & 1738.3 & 20.00 & 319.00 & 91.10 & 711.60 \\
Kappaphycus alvarezii & 10.45 & 101.8 & 10.95 & 230.60 & 25.25 & 1076.60 \\
Sargassum binderi (Sargassum Pjg). & 1.75 & 78.87 & 7.67 & 258.30 & 17.67 & 392.30 \\
Sargassum siliquosum (Sargassum Besar). & 1.54 & 114.50 & 1.33 & 24.70 & 16.03 & 125.46 \\
Padina australis & 3.16 & 19.39 & 1.22 & 2.20 & 2.97 & 39.37 \\
\hline
\end{tabular}

Kepekatan dalam pmol L ${ }^{-1}$

untuk $\mathrm{CHBr}_{3}, 29.4$ pmolL $^{-1}$ untuk $\mathrm{CH}_{2} \mathrm{Br}_{2}$ dan 18.3 pmolL $^{-1}$ untuk $\mathrm{CHBr}_{2} \mathrm{Cl}$. Manakala, pengeluar yang terendah merupakan Caulerpa racemosa var. macrophysa, yang melepaskan sebatian bromin yang rendah dengan nilai 29 pmolL ${ }^{-1}$ untuk $\mathrm{CHBr}_{3}, 6.95$ untuk $\mathrm{CH}_{2} \mathrm{Br}_{2}$ dan 8.17 untuk $\mathrm{CHBr}_{2} \mathrm{Cl}$ (Rajah 2). Meskipun begitu, 'makroalga artik' yang dikaji oleh Laturnus (1996) menunjukkan bahawa makroalga perang dan hijau mengeluarkan $\mathrm{CHBr}_{3}$ yang lebih tinggi daripada makroalga merah (Rajah 3 ).

Kajian mengenai alga dari temperat dan kutub telah banyak dilakukan (Gschwend et al. 1985; Laturnus 1996; Malin \& Liss 1995; Manley \& Dastoor 1988; Manley et al. 2011; Nightingale et al. 2000) namun, hanya beberapa spesies dari sub-tropika dan tropika sahaja yang dikaji oleh Abrahamsson et al. (1995) dan Collén et al. (1994). Walau bagaimanapun, Ekdahl et al. (1998) menyatakan bahawa spesies alga dari kutub merupakan pengeluar halokarbon yang terendah jika dibandingkan dengan subtropika dan tropika yang disebabkan oleh keamatan cahaya yang tinggi dan perbezaan geografi. Hasil daripada lopak pasang surut (Ekdahl et al. 1998) dan Lautan Atlantik Selatan (Abrahamsson et al. 2004) dilihat membentuk corak profil kepekatan yang sama untuk kajian ini. Kebanyakan pemboleh ubah yang dicerap di dalam kajian ini dan kajian Ekdahl et al. (1998) mungkin disebabkan oleh perbezaan keadaan cahaya dan suhu yang berlainan sewaktu pengukuran diambil.

Seperti yang dinyatakan sebelum ini, kesemua rumpai laut yang terpilih didedahkan kepada keadaan semula jadi dan disimpan di dalam tangki di pusat pengkulturan manakala kaedah kerja Ekdahl et al. (1998) pula berdasarkan spesies makroalga temperat dan pengukuran dilakukan secara in-situ di kawasan kajian. Meskipun terdapat perbezaan sewaktu menjalankan
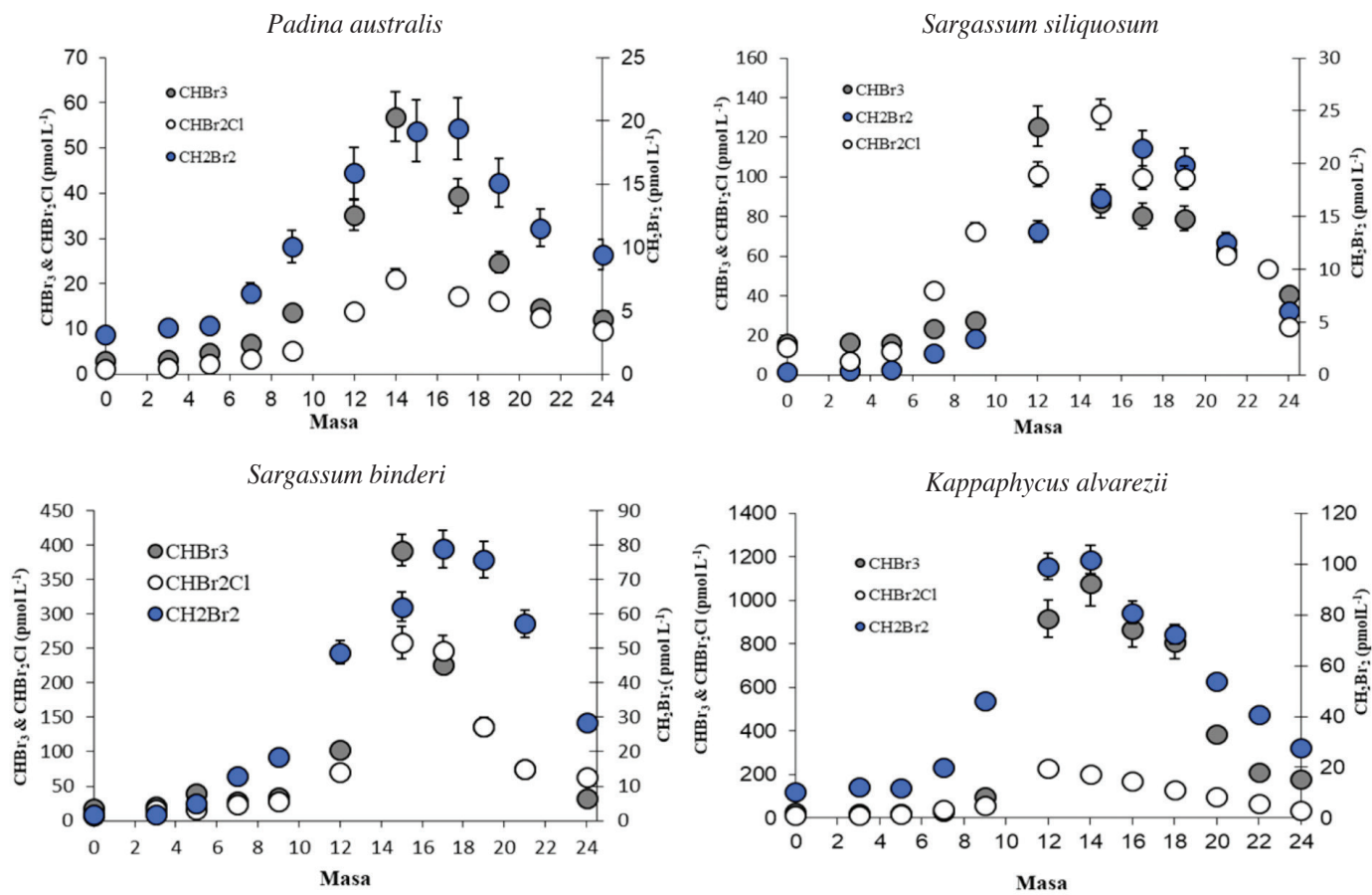

RAJAH 1. Kepekatan bromokarbon VSLS yang dilepaskan oleh rumpai laut perang di dalam air laut 
Ulva reticulata

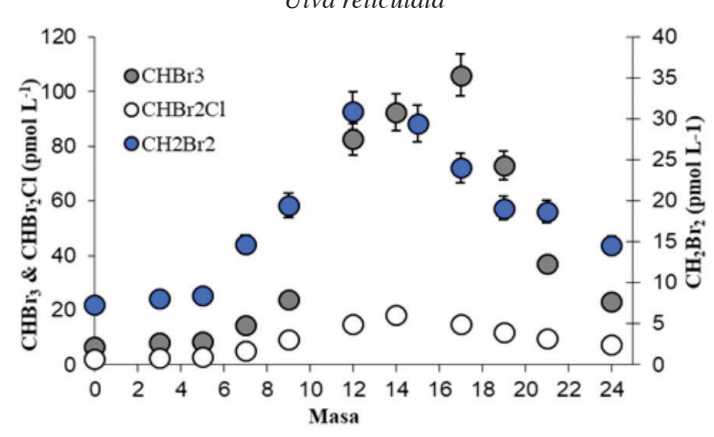

Caulerpa racemosa var. macrophysa

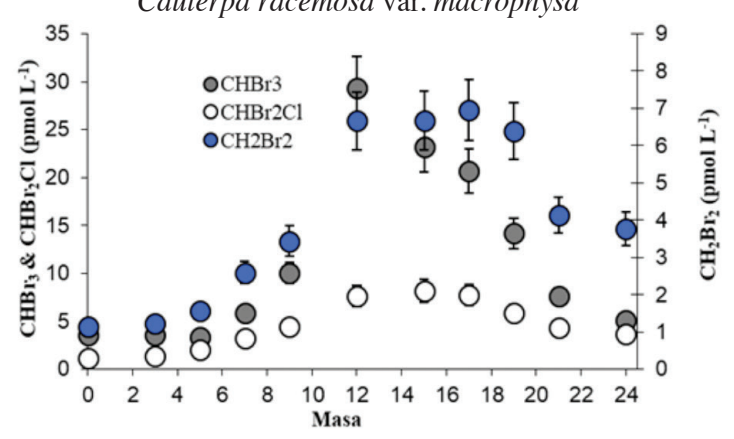

RAJAH 2. Kepekatan bromokarbon VSLS yang dilepaskan oleh rumpai laut hijau di dalam air laut

\section{Gracilaria changii}

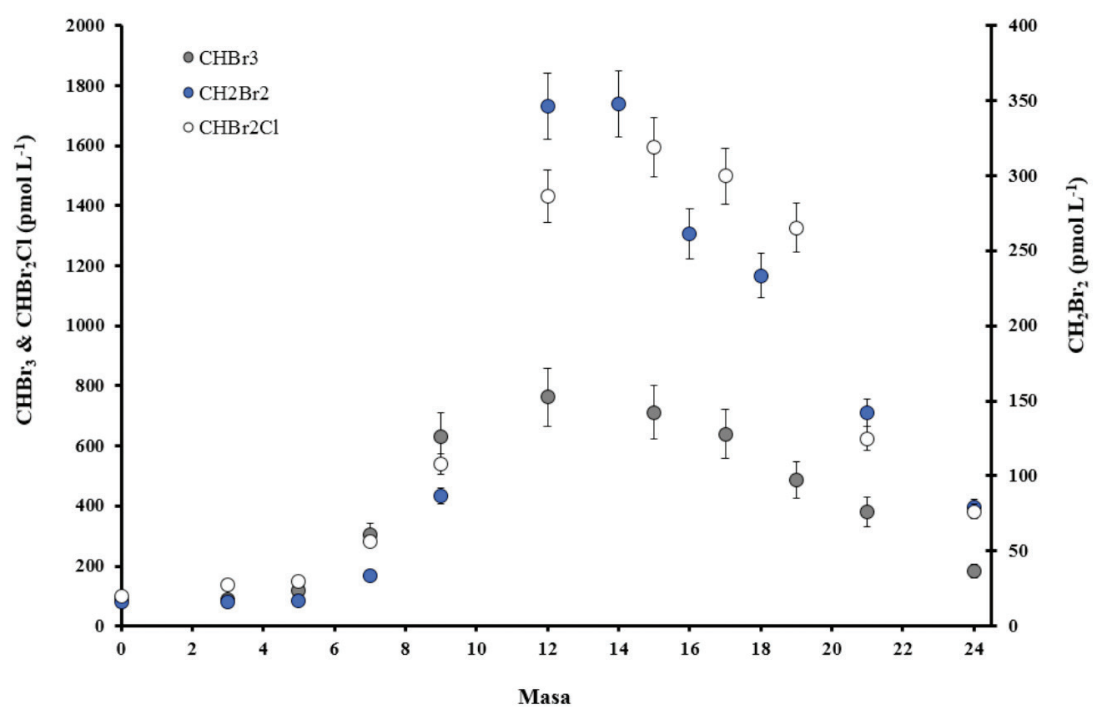

RAJAH 3. Kepekatan bromokarbon VSLS yang dilepaskan oleh rumpai laut merah di dalam air laut

kedua-dua kajian, namun pengukuran bagi kajian ini masih dicatatkan di dalam tempoh asas yang sama iaitu 24 jam. Sampel air laut kawalan (tanpa rumpai laut) telah dirawat menggunakan kaedah yang sama seperti sampel air laut yang mengandungi rumpai laut.

Kepekatan sebatian bromin $\mathrm{CHBr}_{3}, \mathrm{CH}_{2} \mathrm{Br}_{2}$ dan $\mathrm{CHBr}_{2} \mathrm{Cl}$ yang dilepaskan daripada rumpai laut perang, merah dan hijau menunjukkan variasi yang signifikan pada siang hari. Secara amnya, kepekatan ini menunjukkan nilai maksimum pada waktu tengahari dan kemudian menurun dalam tempoh beberapa jam. Rajah 1 hingga 3 menunjukkan siri masa untuk ketiga-tiga sebatian bromin dilepaskan di kawasan air laut yang mengandungi rumpai laut seperti rumpai laut perang (Sargassum binderi, Sargassum siliquosum, Padina australis dan Kappaphycus alvarezii, rumpai laut merah (Gracilaria changii) dan rumpai laut hijau (Ulva reticulata dan Caulerpa racemosa var. macrophysa). Tambahan lagi, analisis P\&T-GC-ECD menunjukkan rumpai laut merah melepaskan bahan jangka hayat pendek (VSLS) bromokarbon yang tertinggi antara ketiga-tiga spesies diikuti oleh rumpai laut perang dan hijau. Hasil kepekatan dinyatakan dalam pmolL ${ }^{-1}$ bagi memudahkan perbandingan dengan data yang sudah diterbit dilakukan.

Keupayaan setiap spesies untuk melepaskan $\mathrm{CHBr}_{2} \mathrm{Cl}$ dan $\mathrm{CH}_{2} \mathrm{Br}_{2}$ dikaitkan dengan pelepasan $\mathrm{CHBr}_{3}$ dan ini memaksudkan suatu mekanisma yang sama seperti tindak balas bromoperoksida (BPO) yang dicadangkan oleh Wever et al. (1997). Namun begitu, kajian yang dilakukan oleh Nightingale et al. (1995) telah menunjukkan terdapat beberapa rumpai laut yang terinkubasi hanya melepaskan $\mathrm{CHBr}_{3}$ tetapi tiada $\mathrm{CH}_{2} \mathrm{Br}_{2}$. Oleh itu, Nightingale mencadangkan bahawa penghasilan bromokarbon lebih kompleks daripada mekanisma yang dinyatakan oleh Wever et al. (1997).

\section{KADAR PENGHASILAN SEBATIAN BROMIN}

Jadual 3 menunjukkan kadar penghasilan halokarbon terbrominasi yang dikira daripada siri masa uji kaji keadaaan semula jadi, dinyatakan di dalam in pmol per gram berat basah (FW) per jam ( $\mathrm{pmol} \mathrm{g}^{-1} \mathrm{FW} \mathrm{h}^{-1}$ ) berdasarkan setiap $100 \mathrm{~g}$ FW rumpai laut. Berdasarkan 
daripada rumpai laut yang dikaji, $\mathrm{CHBr}_{3}$ dikeluarkan pada kadar yang sangat tinggi untuk Kappaphycus alvarezii yang membawa kepada idea bahawa spesies ini berkemungkinan menjadi pelepas bromin yang penting ke atmosfera dengan nilai $74.2 \mathrm{pmol} \mathrm{g}^{-1} \mathrm{FW} \mathrm{h}^{-1}$. Hanya Gracilaria changii sahaja yang menunjukkan penghasilan jumlah $\mathrm{CH}_{2} \mathrm{Br}_{2}$ yang signifikan, ini kerana kesemua spesies yang dikaji hanya melepaskan bromin sebagai $\mathrm{CHBr}_{3}$.

Jadual 4 menunjukkan pelepasan bromin pada setiap jam dan peratus sumbangan setiap halokarbon diukur. Sebahagian besar bromin dilepaskan oleh rumpai laut merah dan beberapa spesies perang manakala spesies hijau seperti Ulva reticulata dan Caulerpa racemosa var. macrophysa dan rumpai laut perang seperti Padina australis menghasilkan kurang daripada 10 pmol Br g-1 FW $\mathrm{h}^{-1}$. Nilai ini juga dilihat sama di dalam kajian Carpenter et al. (2000) bagi makroalga perang (Halidrys siliquosa) temperat. Manley et al. (2011) juga menyatakan Ulva sp. menghasilkan $3.6 \times 104 \mathrm{mg} \mathrm{g}^{-1} \mathrm{FW}^{-1} \mathrm{~d}^{-1}$ dan $1.2 \times 102 \mathrm{mg}$ $\mathrm{g}^{-1} \mathrm{FW}^{-1} \mathrm{~d}^{-1}$ untuk $\mathrm{CHBr}_{3}$ dan $\mathrm{CH}_{2} \mathrm{Br}_{2}$.

Kajian ini juga menunjukkan bahawa rumpai laut perang tropika mempunyai kadar penghasilan $\mathrm{CHBr}_{3}$ yang lebih rendah antara $2.68 \mathrm{ke}^{7} 7.2 \mathrm{pmol} \mathrm{g}^{-1} \mathrm{FW} \mathrm{h}^{-1}$ berbanding kepada rumpai laut perang temperat yang diukur oleh Carpenter et al. (2000) dalam kadar $2.61 \mathrm{ke}$ $196 \mathrm{pmol} \mathrm{g}^{-1} \mathrm{FW} \mathrm{h}^{-1}$ (kecuali Halidrys siliquosa). Namun begitu, menurut kajian Carpenter et al. (2000) terdapat juga kadar penghasilan $\mathrm{CHBr}_{3}$ yang lebih rendah tercatat oleh rumpai laut merah tropika. Di dalam kajian Ekdahl et al. (1998) menyatakan uji kaji inkubasi bagi rumpai laut merah sub-tropika dan tropika (H. spinella, F. hillebrandii dan Gracillaria cornea) mempunyai kadar penghasilan $\mathrm{CHBr}_{3}\left(1 \mathrm{pmol} \mathrm{g}^{-1} \mathrm{FW} \mathrm{h}^{-1}\right)$ yang rendah berbanding kepada penemuan dalam kajian ini, namun begitu kajian ini mencatatkan kadar penghasilan yang sangat tinggi bagi $F$. hillebrandii (200 $\left.\mathrm{pmol} \mathrm{g}^{-1} \mathrm{FW} \mathrm{h}^{-1}\right)$. Oleh itu, dapat dilihat bahawa kadar penghasilan untuk $\mathrm{CHBr}_{3}$ berbeza bagi setiap spesies di lokasi yang berbeza kerana aspek klimatologi yang berlainan.

Penghasilan halokarbon yang tepat daripada sumber biogenik memerlukan pengetahuan perubahan potensi dalam pelepasan makrofit yang disebabkan oleh perubahan fizikal luaran, contohnya perubahan cahaya dan suhu, tindakan gelombang dan tekanan osmosis (Carpenter et al. 2000). Keamatan cahaya yang tinggi menghasilkan tekanan kepada rumpai laut yang boleh menyebabkan peningkatan kadar sel oksigen spesies yang aktif termasuk hidrogen peroksida $\left(\mathrm{H}_{2} \mathrm{O}_{2}\right)$ sebagai produk akhir bagi fotosintesis oksigenik. Menurut Vilter (1995) dan Wever et al. (1991), kehadiran $\mathrm{H}_{2} \mathrm{O}_{2}$ menyebabkan BPO yang berada di dalam sel rumpai laut akan memangkinkan sebatian halogen di dalam rumpai laut.

Kepekatan halokarbon biogenik yang tertinggi biasanya tercatat pada waktu tengahari apabila fotosintesis berada pada tahap maksimum (Abrahamsson et al. 2004). Walau bagaimanapun, kajian oleh Collén et al. (1994) menunjukkan makroalga menghasilkan halokarbon meskipun di dalam keadaan gelap disebabkan oleh aktiviti biologi seperti respirasi berbanding dengan fotosintesis. Pemerhatian yang sama juga dilihat sewaktu uji kaji

JADUAL 3. Kadar pengeluaran sebatian terbrominasi yang dihasilkan secara semula jadi di dalam botol inkubasi $1000 \mathrm{~mL}$ untuk pelbagai jenis rumpai laut

\begin{tabular}{lccc}
\hline Spesies & \multicolumn{3}{c}{ Sebatian } \\
\cline { 2 - 4 } & $\mathrm{CH}_{2} \mathrm{Br}_{2}$ & $\mathrm{CHBr}_{2} \mathrm{Cl}$ & $\mathrm{CHBr}_{3}$ \\
\hline Ulva reticulata & 1.97 & 1.06 & 6.33 \\
Caulerpa racemosa var. macrophysa & 0.46 & 0.54 & 2.14 \\
Gracilaria changii & 137.40 & 22.20 & 55.90 \\
Kappaphycus alvarezii & 7.39 & 18.30 & 74.20 \\
Sargassum binderi & 1.51 & 5.23 & 8.98 \\
Sargassum siliquosum & 5.91 & 1.36 & 9.12 \\
Padina australis & 1.06 & 1.07 & 2.68 \\
\hline
\end{tabular}

Kadar dicatat dalam pmol per $\mathrm{g}^{-1} \mathrm{FW}^{-1} \mathrm{~h}^{-1}$

JADUAL 4. Jumlah pelepasan bromin untuk rumpai laut yang diambil di pesisir Port Dickson dan Tanjung Balau

\begin{tabular}{lcccc}
\hline \multicolumn{1}{c}{ Spesies } & \multicolumn{3}{c}{ Jumlah sumbangan kepada pelepasan $\mathrm{Br}, \%$} \\
\multicolumn{1}{c}{ Jumlah $\mathrm{Br}, \mathrm{pmol} \mathrm{g}^{-1} \mathrm{FW} \mathrm{h}^{-1}$} & $\mathrm{CHBr}_{2} \mathrm{Cl}$ & $\mathrm{CH}_{2} \mathrm{Br}_{2}$ & $\mathrm{CHBr}_{3}$ \\
\hline Ulva reticulata & 9.37 & 11.30 & 21.10 & 67.60 \\
Caulerpa racemosa var. macrophysa & 3.14 & 17.20 & 14.70 & 68.20 \\
Gracilaria changii & 215.50 & 10.30 & 63.80 & 25.90 \\
Kappaphycus alvarezii & 99.30 & 18.30 & 7.39 & 74.30 \\
Sargassum binderi & 15.80 & 33.40 & 37.50 & 56.90 \\
Sargassum siliquosum & 16.40 & 8.30 & 9.23 & 55.60 \\
Padina australis & 4.81 & 55.80 & 22.10 & 55.80 \\
\hline
\end{tabular}


malam dijalankan dengan kebanyakan spesies masih menghasilkan bromin VSLS pada kepekatan yang rendah. Hipotesis ini mungkin disebabkan oleh pelepasan makrofit di dalam keadaan gelap. Tambahan lagi, Vogel et al. (1987) menyimpulkan bahawa penurunan kepekatan dari siang ke malam adalah disebabkan oleh degradasi abiotik halokarbon yang meruap di dalam air laut, namun begitu, penyebab penurunan ini masih lagi kurang dibuktikan. Walau bagaimanapun, penurunan kepekatan halokarbon ini berkemungkinan ada kaitan dengan proses sejatan ke atmosfera. Masa penghasilan halokarbon ditentukan melalui kepekatan air yang diplot melawan masa. Untuk mengganggar kadar penghasilan halokarbon bagi setiap spesies, pengukuran purata kepekatan halokarbon pada masa permulaan (diambil sebagai masa sifar) harus ditolak daripada nilai kepekatan yang maksimum pada waktu tengahari dan dibahagikan dengan masa kepekatan halokarbon maksimum dicatatkan.

\section{PARAMETER YANG MEMPENGARUHI PENGHASILAN HALOKARBON}

$C h l$-a Chl- $a$ pigmen penting bagi proses fotosintesis dalam fitoplankton dan kepekatan chl- $a$ di dalam sampel air laut digunakan untuk menganggarkan biojisim dan kapasiti fotosintesis fitoplankton. Ia kerana chl- $a$ merupakan pigmen yang kebiasaannya dijumpai di kebanyakan fitoplakton marin (Li et al. 2002). Tambahan lagi, nilai chl- $a$ yang tinggi juga menunjukkan biojisim fitoplankton yang tinggi di dalam air laut dan ia juga dikaitkan dengan bahan jangka hayat pendek (VSLS) halokarbon di lautan terbuka (Carpenter et al. 2007; Scarratt \& Moore 1999). Oleh itu, pengukuran chl- $a$ sangat penting untuk menentukan kepekatan VSLS halokarbon di dalam air laut. Rajah 4 menunjukkan purata chl- $a$ dan keamatan cahaya sepanjang tempoh uji kaji dijalankan untuk sembilan replika air laut yang ditapis.
Nilai in-situ chl- $a$ diambil setiap kali sebelum analisis P\&T GC-ECD untuk air laut yang ditapis dilakukan. Kajian ini membuktikan bahawa nilai chl- $a$ akan menentukan corak pelepasan halokarbon untuk keseluruhan tempoh masa 24 jam. Nilai maksimum $0.57 \mathrm{mgm}^{-3}( \pm 3.9)$ dicatatkan pada waktu tengahari (12 pm) apabila keamatan cahaya berada

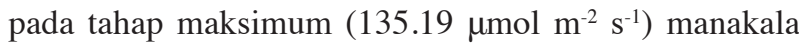
nilai terendah $0.012 \mathrm{mgm}^{-3}( \pm 0.9)$ dicatatkan pada waktu malam (12 pagi) apabila keamatan cahaya berada pada tahap minimum $\left(0 \mu \mathrm{mol} \mathrm{m} \mathrm{m}^{-2} \mathrm{~s}^{-1}\right)$. Menurut Marra dan Heinemann (1982), fitoplakton akan tumbuh dengan pesat di dalam air laut pada pertengahan hari kerana pada ketika itu kadar fotosintetik mencapai tahap maksimum. Scarratt dan Moore (1999) melaporkan bahawa mikroalga merah (Porphyridium purpureum) tumbuh dengan pesat dan mencatatkan nilai kandungan chl- $a$ yang tinggi apabila diletakkan di bawah cahaya pendarfluor selama empat hari. Hasil daripada kajian ini menunjukkan bahawa kepekatan chl- $a$ boleh digunakan sebagai proksi untuk kepekatan SVLS bromokarbon permukaan air laut dan untuk kepekatan anomali VSLS bromokarbon disebabkan oleh kolerasi yang kuat dengan kepekatan chl- $a$. Walau bagaimanapun, seperti yang dinyatakan oleh beberapa kajian terdahulu, keadaan ini tidak mungkin berlaku kerana kehadiran organisma khusus yang lain yang kebanyakannya melepaskan halokarbon yang tidak berkolerasi dengan kepekatan pukal chl- $a$ terutamanya di lautan pesisir dan lautan terbuka.

Cahaya dan suhu Jadual 5 menunjukkan korelasi antara VSLS bromokarbon yang dilepaskan di persekitaran air laut dan parameter persekitaran diukur (chl- $a$, suhu permukaan dan keamatan cahaya). Setiap parameter menunjukkan korelasi yang tinggi dengan pelepasan VSLS bromokarbon daripada setiap jenis rumpai laut yang berbeza. Walau bagaimanapun, beberapa sebatian VSLS menunjukkan korelasi yang lemah dengan chl- $a$. Kedua-dua rumpai

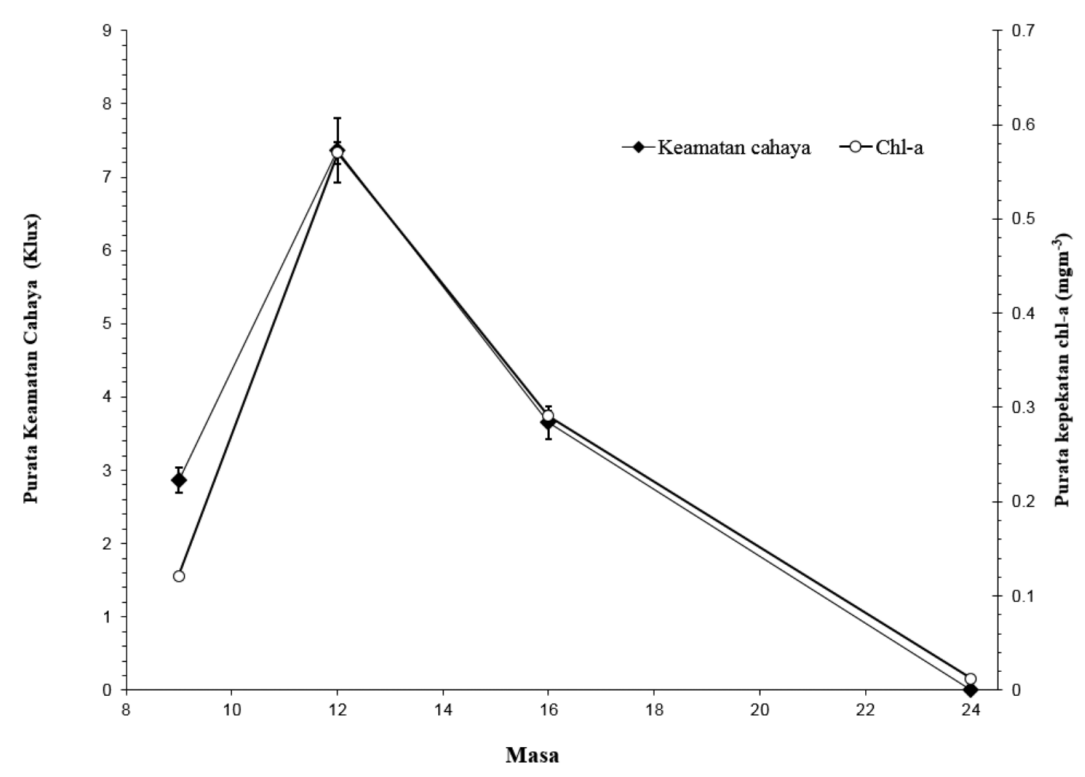

RAJAH 4. Julat keamatan cahaya dan chl-a in-situ untuk tempoh 24 jam ketika uji kaji pengkulturan 
JADUAL 5. Korelasi antara parameter persekitaran dengan pelepasan bromokarbon VSLS semasa uji kaji pengkulturan rumpai laut

\begin{tabular}{|c|c|c|c|c|c|c|c|c|c|}
\hline \multirow[b]{2}{*}{ Spesies } & \multicolumn{3}{|c|}{$\mathrm{CHBr}_{3}$} & \multicolumn{3}{|c|}{$\mathrm{CH}_{2} \mathrm{Br}_{2}$} & \multicolumn{3}{|c|}{$\mathrm{CHBr}_{2} \mathrm{Cl}$} \\
\hline & $\begin{array}{c}\text { Keamatan } \\
\text { cahaya }\end{array}$ & Chl- $a$ & $\begin{array}{l}\text { Suhu air } \\
\text { laut }\end{array}$ & $\begin{array}{c}\text { Keamatan } \\
\text { cahaya }\end{array}$ & Chl- $a$ & $\begin{array}{c}\text { Suhu air } \\
\text { laut }\end{array}$ & $\begin{array}{c}\text { Keamatan } \\
\text { cahaya }\end{array}$ & Chl- $a$ & $\begin{array}{c}\text { Suhu air } \\
\text { laut }\end{array}$ \\
\hline Ulva reticulata & $r^{2}=0.41$ & $r^{2}=0.14$ & $r^{2}=0.75$ & $r^{2}=0.97$ & $\mathrm{r}^{2}=0.75$ & $\mathrm{r}^{2}=0.93$ & $r^{2}=0.69$ & $\mathrm{r}^{2}=0.39$ & $r^{2}=0.91$ \\
\hline $\begin{array}{l}\text { Caulerpa racemosa var. } \\
\text { macrophysa }\end{array}$ & $\mathrm{r}^{2}=0.91$ & $\mathrm{r}^{2}=0.81$ & $\mathrm{r}^{2}=0.98$ & $r^{2}=0.66$ & $\mathrm{r}^{2}=0.37$ & $\mathrm{r}^{2}=0.90$ & $\mathrm{r}^{2}=0.51$ & $\mathrm{r}^{2}=0.54$ & $\mathrm{r}^{2}=0.86$ \\
\hline Gracilaria changii & $r^{2}=0.83$ & $r^{2}=0.84$ & $r^{2}=0.98$ & $r^{2}=0.83$ & $r^{2}=0.82$ & $r^{2}=0.64$ & $r^{2}=0.62$ & $r^{2}=0.66$ & $r^{2}=0.61$ \\
\hline Kappaphycus alvarezii & $\mathrm{r}^{2}=0.52$ & $r^{2}=0.78$ & $\mathrm{r}^{2}=0.92$ & $\mathrm{r}^{2}=0.50$ & $\mathrm{r}^{2}=0.94$ & $\mathrm{r}^{2}=0.97$ & $\mathrm{r}^{2}=0.41$ & $r^{2}=0.96$ & $\mathrm{r}^{2}=0.99$ \\
\hline Sargassum binderi & $\mathrm{r}^{2}=0.84$ & $r^{2}=0.39$ & $\mathrm{r}^{2}=0.97$ & $\mathrm{r}^{2}=0.97$ & $\mathrm{r}^{2}=0.40$ & $\mathrm{r}^{2}=0.97$ & $\mathrm{r}^{2}=0.82$ & $r^{2}=0.42$ & $\mathrm{r}^{2}=0.97$ \\
\hline Sargassum siliquosum & $r^{2}=0.74$ & $r^{2}=0.95$ & $r^{2}=0.94$ & $r^{2}=0.74$ & $r^{2}=0.95$ & $r^{2}=0.94$ & $r^{2}=0.74$ & $r^{2}=0.95$ & $r^{2}=0.95$ \\
\hline Padina australis & $\mathrm{r}^{2}=0.79$ & $\mathrm{r}^{2}=0.95$ & $\mathrm{r}^{2}=0.93$ & $\mathrm{r}^{2}=0.83$ & $\mathrm{r}^{2}=0.83$ & $\mathrm{r}^{2}=0.99$ & $r^{2}=0.49$ & $\mathrm{r}^{2}=0.47$ & $\mathrm{r}^{2}=0.83$ \\
\hline
\end{tabular}

laut hijau Ulva reticulata dan Caulerpa racemosa var. macrophysa menunjukkan korelasi lemah yang signifikan dengan chl-a kecuali pelepasan $\mathrm{CHBr}_{3}$ dari Caulerpa racemosa var. macrophysa $\left(\mathrm{r}^{2}=0.81, \mathrm{p}<0.01\right)$. Nilai korelasi $\mathrm{r}^{2}$ pelepasan bromokarbon $\left(\mathrm{CHBr}_{3}\right.$ dan $\left.\mathrm{CHBr}_{2} \mathrm{Cl}\right)$ dengan chl- $a$ dari Ulva reticulata ialah 0.14 dan 0.39 , menunjukkan bahawa bromokarbon yang dilepaskan ke dalam air laut lebih tinggi daripada fitoplakton atau daripada rumpai laut lain.

Kebanyakan rumpai laut merah dan perang yang diukur menunjukkan kolerasi yang agak kuat dengan chl- $a$ dan keamatan cahaya. Pemerhatian ini membawa kepada idea bahawa semua vSLS bromokarbon mungkin dilepaskan secara terus daripada rumpai laut dan fitoplankton ke dalam persekitaran air laut. Abrahamsson et al. (1995) melaporkan bahawa tekanan cahaya yang tinggi dapat merangsang penghasilan halokarbon dalam alga merah di dalam air laut. Namun begitu, sebatian iodin lain seperti metil iodida $\left(\mathrm{CH}_{3} \mathrm{I}\right)$ menunjukkan korelasi yang baik dalam tempoh tertentu sahaja. Sebagai contoh, Richter (2003) menyatakan pada waktu tertentu $\mathrm{CH}_{3} \mathrm{I}$ yang dikeluarkan adalah tinggi apabila nilai chl- $a$ juga tinggi tetapi bukan sepanjang tempoh bacaan diambil. Oleh itu, isu yang berkaitan korelasi antara kandungan chl- $a$ dan pelepasan halokarbon di dalam air laut masih lagi dibincangkan (Abrahamsson \& Ekdahl 1993; Hughes 2001; Moore \& Groszko 1999; Schall et al. 1997).

Korelasi antara chl- $a$ atau kandungan pigmen yang lain dengan penghasilan halokarbon masih lagi menjadi persoalan bagi para penyelidik. Abrahamsson dan Ekdahl (1993) tidak dapat mengesan sebarang korelasi antara kepekatan metil iodida dan kandungan chl- $a$ di Selat Skagerrak. Schall et al. (1997) pula mendapati korelasi yang lemah antara pelepasan metil iodida dan kepekatan chl- $a$ di Atlantik, meskipun ada ketika nilai chl- $a$ berada pada nilai yang rendah sama seperti dengan kepekatan $\mathrm{CH}_{3} \mathrm{I}$. Moore dan Groszko (1999) tidak menemukan korelasi keseluruhan antara chl- $a$ dan kepekatan $\mathrm{CH}_{3} \mathrm{I}$ dalam data dari Atlantik timur dan Pasifik tetapi menjumpai beberapa hubungan antara kedua-dua parameter dalam skala masa yang pendek. Ini mungkin disebabkan oleh penghasilan $\mathrm{CH}_{3} \mathrm{I}$ oleh organisma tertentu dan kelimpahannya tidak berkolerasi dengan kepekatan pukal chl-a (Moore \& Groszko 1999). Hughes (2001) tidak menjumpai kolerasi yang signifikan dalam keseluruhan set data juga menggunakan hujah yang sama namun sekali lagi ia ditetapkan sebagai petunjuk beberapa korelasi antara $\mathrm{CH}_{3} \mathrm{I}$ dan pigmen tertentu ke atas skala ruang yang kecil.

Parameter meteorologi seperti keamatan cahaya dan suhu permukaan laut (SST) boleh mempengaruhi kadar kepekatan dan pengeluaran VSLS bromokarbon ke atmosfera dan kepekatan permukaan chl- $a$ kerana ia dapat mempengaruhi proses fotosintesis. Spesies yang mempunyai kolerasi tertinggi dengan keamatan cahaya ialah Ulva reticulata $\left(\mathrm{r}^{2}=0.97\right)$ dan spesies yang mempunyai korelasi yang terendah ialah Kappaphycus alvarezii ( $\mathrm{r} 2=0.41)$. Ini mungkin disebabkan oleh keberhasilan Kappaphycus alvarezii yang rendah di kawasan pasang surut berbanding spesies lain dalam kajian ini. Kajian terdahulu oleh Laturnus et al. (1998) telah menyatakan bahawa tiada hubungan yang jelas antara kebergantungan cahaya dengan makroalga Antartika dan ini mungkin disebabkan oleh keadaan semasa musim sejuk di Antartika yang boleh menyumbang kepada pembentukan kepekatan halokarbon. Hasil pengeluaran VSLS bromokarbon dalam kajian ini akan memberi sedikit pencerahan sekiranya ada kolerasi dengan kandungan chl- $a$ dan keamatan cahaya.

\section{AKTIVITI BROMOPEROKSIDA}

Aktiviti bromoperoksida (BPO) dalam rumpai laut telah banyak dikaji dan direkodkan (Jittam et al. 2009; Wever et al. 1991). Itoh dan Shinya (1994) dan Ohshiro et al. (2002) telah melaporkannya di dalam kajian alga merah marin, Corallina pilulifera. Seperti yang ditunjukkan di dalam Jadual 6, jumlah aktiviti BPO yang tertinggi dilihat di dalam rumpai laut merah Gracilaria changii yang mencatat 186.5 Units dan diikuti oleh rumpai laut perang dan hijau. Sargassum binderi mencatat nilai aktiviti 186.5 Units manakala Sargassum siliquosum menunjukkan nilai aktiviti 48.2 Units. Meskipun begitu, Kappaphycus 
JADUAL 6. Taburan aktiviti BPO di dalam rumpai laut merah, perang dan hijau daripada uji kaji penghasilan halokarbon

\begin{tabular}{|c|c|c|c|c|c|c|}
\hline Pengekstrakan mentah & $\begin{array}{l}\text { Jumlah } \\
\text { protein } \\
(\mathrm{mg} / \mathrm{ml})\end{array}$ & $\begin{array}{c}\text { Jumlah } \\
\text { aktiviti BPO } \\
\text { (Units) }\end{array}$ & $\begin{array}{c}\text { Jumlah aktiviti BPO } \\
\text { setiap rumput laut } \\
(\mathrm{U} / \mathrm{g} \mathrm{FW})\end{array}$ & $\begin{array}{c}\text { Aktiviti spesifik } \\
\text { BPO } \\
\text { (Units/mg) }\end{array}$ & Lipatan & $\begin{array}{c}\text { Hasil } \\
(\%)\end{array}$ \\
\hline Gracilaria changii & 65 & 187 & 1.9 & 0.6 & 1 & 100 \\
\hline Ulva reticulata & 11 & $8 \times 10^{-3}$ & $8.4 \times 10^{-4}$ & $7.8 \times 10^{-2}$ & 1 & 100 \\
\hline Padina australis & 11 & 23 & 0.02 & 0.2 & 1 & 100 \\
\hline Sargassum binderi & 52 & 104 & 1 & 0.2 & 1 & 100 \\
\hline Sargassum siliquosum & 46 & 48 & 0.5 & 0.1 & 1 & 100 \\
\hline Kappaphycus alvarezii & 30 & 28 & 0.3 & 0.2 & 1 & 100 \\
\hline Caulerpa racemosa var. macrophysa & 1 & $3.2 \times 10^{-4}$ & $3.2 \times 10^{-6}$ & $1.6 \times 10^{-4}$ & 1 & 100 \\
\hline
\end{tabular}

alvarezii yang menghasilkan $\mathrm{CHBr}_{3}$ yang paling tinggi sewaktu uji kaji sistem pengkulturan dan dijangkakan untuk mencatatkan nilai aktiviti BPO yang tinggi, hanya mencatat nilai sebanyak 28 Units. Ini mungkin disebabkan oleh spesies ini sukar untuk disimpan segar selama 1 minggu.

Hasil kajian ini bagi rumpai laut merah adalah sepadan jika dibandingkan laporan awal berkenaan pelepasan bahan halogen di dalam ekstrak alga merah oleh Fenical (1975) dan Faulkner (1980). Kedua-dua kajian melaporkan bahawa makroalga merah dianggap sebagai sumber yang banyak untuk halokarbon. Itoh dan Shinya (1994) juga menyatakan yang famili alga merah Corallinaceae melepaskan kepekatan bromometana yang tinggi dan kumpulan alga ini sahaja mampu menyebabkan input bromometana ke Hemisfera Utara sebanyak 5,000 hingga 10,000 metrik tan pada setiap musim bunga.

Oleh itu, hasil daripada uji kaji cerakinan enzim menunjukkan aktiviti BPO yang tinggi boleh dikorelasikan dengan pelepasan halokarbon VSLS yang tinggi daripada rumpai laut. Ini selari dengan pemerhatian Wever (1988) yang menyatakan kepekatan $\mathrm{CHBr}_{3}$ yang maksimum di atmosfera Artik adalah semasa tempoh aktiviti pertumbuhan yang tinggi dan aktiviti BPO yang tinggi di dalam alga. Collén et al. (1994) melaporkan penghasilan $\mathrm{H}_{2} \mathrm{O}_{2}$ di dalam alga boleh meningkatkan jumlah halokarbon yang terbrominasi dan berklorin. Ini kerana penghapusan $\mathrm{H}_{2} \mathrm{O}_{2}$ di dalam sel tisu rumpai laut oleh BPO yang terletak di dinding sel akan membawa kepada pembentukan hipoklorit yang bebas atau pembentukan hipoklorit yang terikat dengan enzim. Hipoklorit ini akan bertindak balas dengan ion bromida dan membentuk hipobromit. Tindak balas hipoklorit dan hipobromit yang terhasil dengan bahan organik larut akan menghasilkan pelbagai sebatian berklorin dan bromin (Ekdahl et al. 1998).

\section{KESIMPULAN}

Bromokarbon vSL $\mathrm{CHBr}_{3}, \mathrm{CH}_{2} \mathrm{Br}_{2}$ dan $\mathrm{CHBr}_{2} \mathrm{Cl}$ yang diukur oleh P\&T GC-ECD di dalam air laut yang mengandungi tujuh jenis rumpai laut yang berbeza iaitu rumpai laut merah, perang dan hijau yang mendominasi kawasan Port Dickson dan Tanjung Balau. Kadar pelepasan sebatian ini disusun mengikut turutan rumpai laut merah> perang $>$ hijau. Pelepasan kepekatan $\mathrm{CH}_{2} \mathrm{Br}_{2}$ yang tinggi dilihat datangnya daripada rumpai laut merah Gracilaria changii dan kepekatan $\mathrm{CHBr}_{3}$ yang tinggi pula daripada rumpai laut perang Kappaphycus alvarezii . Korelasi yang kuat daripada sebatian bromokarbon ini menunjukkan bahawa jika tapak kajian terletak di daratan, maka nisbah pencampuran bromokarbon yang tinggi datang dari dataran rumpai laut yang berdekatan. Pemerhatian ini disokong oleh uji kaji sistem pengkulturan dengan nisbah $\mathrm{CH}_{2} \mathrm{Br}_{2} /$ $\mathrm{CHBr}_{3}$ ialah 0.3 dan 0.2 di dalam air laut dan atmosfera. Parameter lain seperti chl- $a$ dan keamatan cahaya perlu diambil kira di dalam pelepasan sebatian ini. Chl- $a$ dan keamatan cahaya in-situ berkolerasi baik dengan kesemua pelepasan bromokarbon VSLS daripada rumpai laut yang terpilih. Ini menunjukkan pelepasan halokarbon meningkat pada tengah hari apabila keamatan cahaya berada di tahap maksimum. Pengekstrakan BPO daripada rumpai laut merah, perang dan hijau menunjukkan aktiviti BPO yang tertinggi dilihat di dalam turutan merah $>$ perang $>$ hijau. Kesimpulannya, hasil kajian ini menunjukkan aktiviti BPO yang lebih tinggi akan menyebabkan kepada pelepasan halokarbon yang lebih tinggi.

\section{PENGHARGAAN}

Penghargaan ditujukan kepada Universiti Kebangsaan Malaysia untuk geran UKM-GUP-2018-031 bagi memuktamadkan kajian ini. Setinggi-tinggi penghargaan juga ditujukan kepada Professor Dr. Phang Siew Moi daripada Institut Bumi dan Sains (IOES), Universiti Malaya bagi kemudahan persampelan yang disediakan di makmal dan kerja lapangan. Terima kasih juga diucapkan kepada Geran Pasca Siswazah Universiti Malaya (PPP) dan British Council atas tajaan geran penyelidikan PMI2, dan kepada Kementerian Sains, Teknologi \& Inovasi (MOSTI), Malaysia atas sokongan kewangan dan peluang yang diberikan kepada Universiti Malaya (UM) untuk MSMN mengambil bahagian dalam penyelidikan ini.

\section{RUJUKAN}

Abrahamsson, K. \& Ekdahl, A. 1993. Gas chromatographic determination of halogenated organic compounds in water and sediment in the Skagerrak. Journal of Chromatography A 643(1): 239-248. 
Abrahamsson, K., Lorén, A., Wulff, A. \& Wängberg, S.Å. 2004. Air-sea exchange of halocarbons: The influence of diurnal and regional variations and distribution of pigments. Deep Sea Research Part II: Topical Studies in Oceanography 51(22-24): 2789-2805.

Abrahamsson, K., Ekdahl, A., Collén, J. \& Pedersén, M. 1995. Marine algae-A source of trichloroethylene and perchloroethylene. Limnology and Oceanography 40(7): 1321-1326.

Almeida, M., Filipe, S., Humanes, M., Maia, M.F., Melo, R., Severino, N., Da Silva, J.A.L., da Silva, J.F. \& Wever, R. 2001. Vanadium haloperoxidases from brown algae of the Laminariaceae family. Phytochemistry 57(5): 633-642.

Aschmann, J., Sinnhuber, B.M., Atlas, E.L. \& Schauffler, S.M. 2009. Modeling the transport of very short-lived substances into the tropical upper troposphere and lower stratosphere. Atmospheric Chemistry and Physics 9(23): 9237-9247.

Auer, N.R., Manzke, B.U. \& Schulz-Bull, D.E. 2006. Development of a purge and trap continuous flow system for the stable carbon isotope analysis of volatile halogenated organic compounds in water. Journal of Chromatography A 1131(1): 24-36.

Carpenter, L.J., Malin, G. \& Liss, P.S. 2000. Novel biogenic iodine-containing trihalomethanes and other. Global Biogeochemical Cycles 14(4): 1191-1204.

Carpenter, L.J., Reimann, S., Burkholder, J.B., Clerbaux, C., Hall, B.D., Hossaini, R., Laube, J.C. \& Yvon-Lewis, S.A. 2014. Update on ozone-depleting substances (ODSs) and other gases of interest to the Montreal Protocol (Chapter 1). In Scientific Assessment of Ozone Depletion: 2014. Geneva: Global Ozone Research and Monitoring Project-Report No. 55, World Meteorological Organization.

Carpenter, L.J., Wevill, D.J., Hopkins, J.R., Dunk, R.M., Jones, C.E., Hornsby, K.E. \& McQuaid, J.B. 2007. Bromoform in tropical Atlantic air from $25^{\circ} \mathrm{N}$ to $25^{\circ} \mathrm{S}$. Geophysical Research Letters 34: 1-5.

Collén, J., Ekdahl, A., Abrahamsson, K. \& Pedersén, M. 1994. The involvement of hydrogen peroxide in the production of volatile halogenated compounds by Meristiella gelidium. Phytochemistry 36(5): 1197-1202.

Ekdahl, A., Pedersén, M. \& Abrahamsson, K. 1998. A study of the diurnal variation of biogenic volatile halocarbons. Marine Chemistry 63(1): 1-8.

Faulkner, D.J. 1980. Natural organohalogen compounds. In The Natural Environment and the Biogeochemical Cycles. The Handbook of Environmental Chemistry, edited by Craig, P.J. Berlin: Springer. p. 251.

Fenical, W. 1975. Halogenation in rhodophyta: A review. Journal of Phycology 11(3): 245-259.

Gschwend, P.M., MacFarlane, J.K. \& Newman, K.A. 1985. Volatile halogenated organic compounds released to seawater from temperate marine macroalgae. Science 227(4690): 1033-1035.

Hughes, C. 2001. Oceanic methyl iodide: Production rates, relationship with photosynthetic pigments and biological loss process. MSc Thesis. Dalhousie University (Unpublished).

Itoh, N. \& Shinya, M. 1994. Seasonal evolution of bromomethanes from coralline algae (Corallinaceae) and its effect on atmospheric ozone. Marine Chemistry 45(1): 95-103.

Itoh, N., Tsujita, M., Ando, T., Hisatomi, G. \& Higashi, T. 1997. Formation and emission of monohalomethanes from marine algae. Phytochemistry 45(1): 67-73.

Jittam, P., Boonsiri, P., Promptmas, C., Sriwattanarothai, N., Archavarungson, N., Ruenwongsa, P. \& Panijpan, B. 2009.
Red seaweed enzyme-catalyzed bromination of bromophenol red: An inquiry-based kinetics laboratory experiment for undergraduates. Biochemistry and Molecular Biology Education 37(2): 99-105.

Keng, F.S.L., Phang, S.M., Rahman, N.A., Leedham, E.C., Hughes, C., Robinson, A.D., Harris, N.R., Pyle, J.A. \& Sturges, W.T. 2013. Volatile halocarbon emissions by three tropical brown seaweeds under different irradiances. Journal of Applied Phycology 25(5): 1377-1386.

Kongkiattikajorn, J. \& Pongdam, S. 2006. Vanadium haloperoxidase from the red alga Gracilaria fisheri. ScienceAsia 32(1): 25-30.

Laturnus, F. 1996. Volatile halocarbons released from arctic macroalgae. Marine Chemistry 55(3-4): 359-366.

Laturnus, F., Adams, F. \& Wiencke, C. 1998. Methyl halides from antarctic macroalgae. Geophysical Research Letters 25: 773-776.

Leedham, E., Phang, S.M., Sturges, W.T. \& Malin, G. 2015. The effect of desiccation on the emission of volatile bromocarbons from two common temperate macroalgae. Biogeosciences 12: $387-398$

Leedham, E., Hughes, C., Keng, F.S.L, Phang, S.M., Malin, G. \& Sturges, W.T. 2013. Emission of atmospherically significant halocarbons by naturally occurring and farmed tropical macroalgae. Biogeosciences 10(6): 3615-3633.

Li, H.P., Gong, G.C. \& Hsiung, T.M. 2002. Phytoplankton pigment analysis by HPLC and its application in algal community investigations. Botanical Bulletin of Academia Sinica 43: 283-290.

Lim, S.J., Mustapha, W.A.W. \& Maskat, M.Y. 2017. Seaweed tea: Fucoidan-rich functional food product development from Malaysian brown seaweed, Sargassum binderi. Sains Malaysiana 46(9): 1573-1579.

Lowry, O.H., Roberts, N.R., Leiner, K.Y., Wu, M.L. \& Farr, A.L. 1954. The quantitative histochemistry of brain I. Chemical methods. The Journal of Biological Chemistry 207: 1-18.

Manley, S.L. \& Dastoor, M.N. 1988. Methyl Iodide (CH3I) production by kelp and associated microbes. Marine Biology 98(4): 477-482.

Manley, S.L., Goodwin, K. \& North, W.J. 2011. Production of bromoform, methylene bromide, and methyl iodide by macroalgae in and distribution nearshore Southern California waters. Limnology 37(8): 1652-1659.

Marra, J. \& Heinemann, K. 1982. Photosynthesis response to sunlight variability by phytoplankton. Limnology and Oceanography 27(6): 1141-1153.

Mithoo-Singh, P.K., Keng, F.S.L., Phang, S.M., Elvidge, E.C.L., Sturges, W.T., Malin, G. \& Rahman, N.A. 2017. Halocarbon emissions by selected tropical seaweeds: Species-specific and compound-specific responses under changing $\mathrm{pH}$. PeerJ 5: $1-22$

Moore, R.M. \& Groszko, W. 1999. Methyl iodide distribution in the ocean and fluxes to the atmosphere. Journal of Geophysical Research 104(C5): 11163-11171.

Nadzir, M.S.M., Phang, S.M., Abas, M.R., Rahman, N.A., Samah, A.A. \& Sturges, W.T. 2014. Bromocarbons in the tropical coastal and open ocean atmosphere during the 2009 Prime Expedition Scientific Cruise (PESC-09). Atmospheric Chemistry and Physics 14: 8137-8148.

Nightingale, P.D., Malin, G. \& Liss, P.S. 1995. Production of chloroform and other low-molecular-weight halocarbons by some species of macroalgae. Limnology and Oceanography 40(4): 680-689. 
Ohshiro, T., Hemrika, W.,Aibara, T., Wever, R. \& Izumi, Y. 2002. Expression of the vanadium-dependent bromoperoxidase gene from a marine macro-alga Corallina pilulifera in Saccharomyces cerevisiae and characterization of the recombinant enzyme. Phytochemistry 60: 595-601.

Phang, S.M., Keng, F.S.L., Paramjeet-Kaur, M.S., Lim, Y.K., Rahman, N.A., Leedham, E., Robinson, A.D., Harris, N.R.P., Pyle, J.A. \& Sturges, W.T. 2015. Can seaweed farming in the tropics contribute to climate change through emission of short-lived halocarbons? Malaysian Journal of Science 34(1): 8-19.

Raimund, S., Quack, B., Bozec, Y., Vernet, M., Rossi, V. \& Garc, V. 2011. Sources of short-lived bromocarbons in the Iberian upwelling system. Biogeosciences 8: 1551-1564.

Richter, U. 2003. Factors influencing methyl iodide production in the ocean and its flux to the atmosphere. PhD Thesis. Christian Albrechts University Kiel (Unpublished).

Robinson, A.D., Harris, N.R.P., Ashfold, M.J., Gostlow, B., Warwick, N.J., Brien, L.M.O., Beardmore, E.J., Mohd Shahrul, Mohd Nadzir., Phang, S.M., Samah, A.A., Ong, S., Ung, H.E., Peng, L.K., Yong, S.E., Mohamad, M. \& Pyle, J.A. 2014. Long-term halocarbon observations from a coastal and an inland site in Sabah, Malaysian Borneo. Atmospheric Chemistry and Physics 14(16): 8369-8388.

Scarratt, M.G. \& Moore, R.M. 1999. Production of chlorinated hydrocarbons and methyl iodide by the red microalga Porphyridium purpureum. Limnology and Oceanography 44(3): 703-707.

Schall, C., Heumann, K.G. \& Kirst, G.O. 1997. Biogenic volatile organoiodine and organobromine hydrocarbons in the atlantic ocean from $42^{\circ} \mathrm{N}$ to $72^{\circ} \mathrm{S}$. Fresenius' Journal of Analytical Chemistry 359(3): 298-305.

Shimonishi, M., Kuwamoto, S., Inoue, H., Wever, R., Ohshiro, T., Izumi, Y. \& Tanabe, T. 1998. Cloning and expression of the gene for a vanadium-dependent bromoperoxidase from a marine macro-Alga, Corallina pilulifera. FEBS Letters 428(1-2): 105-110.

Vilter, H. 1995. Vanadium-Dependent Haloperoxidases. In Metal Ions in Biological Systems, edited by Sigel, H. \& Sigel, A. Volume 35. New York: Marcel Dekker.

Vogel, T.M., Criddle, C.S. \& McCarty, P.L. 1987. ES Critical Reviews: Transformations of halogenated aliphatic compounds. Environmental Science \& Technology 21(8): 722-36.

Wever, R. 1988. Ozone destruction by algae in the arctic atmosphere. Nature 335(6190): 501-501.

Wever, R., Barnett, P. \& Hemrika, W. 1997. Structure and physiological function of vanadium chloroperoxidase. In Iron and Related Transition Metals in Microbial Metabolism, edited by Winkelman, G. \& Carrano, C.J. Amsterdam: Harwood Academic Publishers. pp. 415-433.

Wever, R., Tromp, M.G.M., Krenn, B.E., Marjani, A. \& Van Tol, M. 1991. Brominating activity of the seaweed ascophyllum nodosum: Impact on the biosphere. Environmental Science \& Technology 25(3): 446-449.
Yip, W.H., Joe, L.S., Mustapha, W.A.W., Maskat, M.Y. \& Said, M. 2014. Characterisation and stability of pigments extracted from Sargassum binderi obtained from Semporna, Sabah. Sains Malaysiana 43(9): 1345-1354.

Chandran Raynusha, Mohammad Rozaimi, Nur Hidayah, Mohd Shahrul Mohd Nadzir*

Pusat Sains Bumi \& Alam Sekitar

Fakulti Sains \& Teknologi

Universiti Kebangsaan Malaysia

43600 UKM Bangi, Selangor Darul Ehsan

Malaysia

Mohd Shahrul Mohd Nadzir*

Pusat Sistem Perubahan Iklim Tropika (IKLIM)

Institut Perubahan Iklim

Universiti Kebangsaan Malaysia

43600 UKM Bangi, Selangor Darul Ehsan

Malaysia

Kuhan Chandru

Pusat Sains Angkasa (ANGKASA)

Institut Perubahan Iklim

Tingkat 5, Bangunan Kompleks Penyelidikan

Universiti Kebangsaan Malaysia

Bangi 43600, Selangor Darul Ehsan

Malaysia

Kuhan Chandru

Jabatan Kimia Fizikal

Universiti Teknologi Kimia

Prag, Technicka 5

16628, Prague6- Dejvice

Republik Czech

Wan Shafrina Wan Mohd Jaafar

Pusat Pencerapan Bumi

Institut Perubahan Iklim

Universiti Kebangsaan Malaysia

43600 UKM Bangi, Selangor Darul Ehsan

Malaysia

Noor Liyana Mat Yajit

Pusat Pengajian Bioteknologi dan Makanan berfungsi

Fakulti Sains dan Teknologi

Universiti Kebangsaan Malaysia

43600 UKM Bangi, Selangor Darul Ehsan

Malaysia

*Pengarang untuk surat-menyurat; email: shahrulnadzir@ukm. edu.my

Diserahkan: 1 April 2019

Diterima: 15 Ogos 2019 